Arq. Bras. Med. Vet. Zootec., v.72, n.4, p.1122-1126, 2020

\title{
Hepatitis E virus infection in buffaloes in South China
}

\author{
[Hepatite E infecção viral em búfalos no Sul da China]

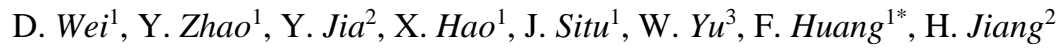 \\ ${ }^{1}$ School of Medical - Kunming University of Science and Technology - Kunming, China \\ ${ }^{2}$ Animal Husbandry Research Institute of Guangxi Zhuang Autonomous Region - Nanning, China \\ ${ }^{3}$ Institute of Medical Biology - Chinese Academy of Medical Sciences and \\ Peking Union Medical College - Kunming, China
}

\begin{abstract}
Hepatitis E virus (HEV) infection is an important global public health issue. HEV infections are recognized as a zoonotic disease. Swine are believed to be the main reservoir of HEV. Recently, yaks, cows, and yellow cattle have been reported as new reservoirs of HEV. However, whether other species of cattle and buffaloes are sensitive to HEV infection is unknown. To investigate the prevalence of HEV infection in buffaloes, enzyme-linked immunosorbent assay (ELISA) and reverse transcription-nested polymerase chain reaction (RT-nPCR) were performed. Only one buffalo was positive to anti-HEV IgM antibody (1/106, 0.94\%), and none were positive for anti-HEV IgG antibody. To our surprise, five serum $(5 / 106,4.72 \%)$ and three milk samples $(3 / 40,7.50 \%)$ from buffaloes were positive to HEV RNA. All strains of HEV isolated from buffaloes belong to genotype 4 . Results indicate that buffaloes may be a new reservoir of HEV.
\end{abstract}

Keywords hepatitis e virus, buffaloes, zoonotic transmission, epidemiology

\section{RESUMO}

Infecção com o vírus Hepatite E (HEV) é uma importante questão de saúde pública global. Infecções HEV são reconhecidas como doença zoológica. Acredita-se que suínos são o principal reservatório de HEV. Recentemente iaques, vacas, e gado amarelo foram reportados como novos reservatórios do HEV. Porém, não se sabe se outras espécies de gado e búfalo são sensíveis a infecção HEV. Para investigar a prevalência de infecção HEV em búfalos, foram realizados prova de imunoabsorção enzimática e polimerização em cadeia inversa ancorada em transcrição. Apenas um búfalo foi positivo para o anticorpo anti-HEV IgM (1/106, 0,94\%), e nenhum foi positivo para o anticorpo anti-HEV IgG. Para nossa surpresa cinco (5/106, $4,72 \%)$ e três amostras de leite (3/40, 7,50\%) de búfalos foram positivos para HEV RNA. Todas as estirpes de HEV isoladas de búfalos pertencem ao genótipo 4. Resultados indicam que búfalos podem ser um reservatório de $\mathrm{HEV}$.

Palavras-chave: hepatite e vírus, búfalo, transmissão zoonótica, epidemiologia

\section{INTRODUCTION}

Hepatitis E virus (HEV) infection is an important global public health issue. It is usually selflimiting, causes approximately 20 million infections and 70,000 deaths every year, and leads to high mortality in pregnant women (Navaneethan et al., 2008; Rein et al., 2012). $\mathrm{HEV}$ is mainly transmitted through the fecal-oral route, but it has been reported to be transmitted through the consumption of uncooked or undercook pork meat (Hoofnagle et al., 2012; Rein et al., 2012).

$\mathrm{HEV}$ infection has been recognized as a zoonotic disease. Swine (Hsieh et al., 1999), camels (Lee et al., 2016), goats (Long et al., 2017), rabbits (Cossaboom et al., 2011) and cows (Hu and $\mathrm{Ma}$,

Recebido em 31 de janeiro de 2019

Aceito em 17 de setembro de 2019

*Autor para correspondência (corresponding author)

E-mail: huangfen6789@kmust.edu.cn 
2010) are natural reservoirs of HEV. The consumption of raw/undercooked pork, liver, or milk has been reported to transmit $\mathrm{HEV}$ to humans or non-human primates $(\mathrm{Hu}$ and $\mathrm{Ma}$, 2010; Huang et al., 2016; Park et al., 2016). In China, HEV has been isolated from Holstein cow (Huang et al., 2016), Yak (Xu et al., 2014), Dairy cow (Hu and $\mathrm{Ma}, 2010)$, and Yellow cattle (Yan et al., 2016), but is rarely reported in buffaloes. Thus, it is important to explore the HEV infection in buffaloes in China.

The HEV RNA genome is a $7.2 \mathrm{~kb}$ positive strand and has at least three open reading frames (ORFs) (Li et al., 2008; Tam et al., 1991). ORF1 encodes the non-structural polyprotein, ORF2 the capsid protein, and ORF3 a small protein involved in virus secretion (Purdy and Khudyakov, 2011). Eight genotypes of HEV are recognized: genotype 1 and $2 \mathrm{HEV}$ infect humans and are endemic in Asia, Africa, and Mexico (Rein et al., 2012). Genotype 3 and 4 HEV infect humans and animals and are endemic in developing and developed countries (Geng et al., 2010; Xu et al., 2014). Genotype $4 \mathrm{HEV}$ has become endemic in China since 2000 (Zhang et al., 2009). Recently, genotype 5 and $6 \mathrm{HEV}$ have been reported in wild boars (Smith et al., 2014, 2015; Takahashi et al., 2011), genotype 7 and 8 HEV has been identified in camel (Lee et al., 2016; Woo et al., 2016).

In the present study, the prevalence of HEV infection in buffaloes in Guangxi province, South China was investigated. The results showed a high prevalence of HEV infection in buffaloes, which suggests that buffaloes may be a new HEV reservoir.

\section{MATERIAL AND METHODS}

To investigate the prevalence of $\mathrm{HEV}$ in buffaloes, a total of 106 blood samples and 40 milk samples were collected from January 2016 to June 2017 from Guangxi Province, China, where most buffaloes are raised. All samples were stored at $-80^{\circ} \mathrm{C}$ until use.

HEV RNA was detected by RT-nPCR according to our previous study (Huang et al., 2002). Both HEV ORF1 and HEV ORF2 were positive, which were defined to be HEV RNA positive (Huang et al., 2016; Huang et al., 2002). Total RNA from blood or milk was extracted using the Axygen kit
(Axygen, China) according to the manufacturer's instructions. RT-nPCR was performed using MMLV reverse transcriptase with specific primers containing the HEV ORF1 and ORF2 genes. The $\mathrm{PCR}$ products were detected using electrophoresis on an agarose gel containing $0.5 \mu \mathrm{g} / \mathrm{mL}$ ethidium bromide.

The seroprevalence of anti-HEV IgG and IgM were determined using a double-antigen sandwich ELISA kit (KHB, China) in accordance to the manufacturer's instructions. The kit used recombinant $\mathrm{HEV}$ fusion proteins derived from putative structural proteins of HEV as a primary antibody. The kit also contained both positive and negative controls.

\section{RESULTS}

Five serum $(5 / 106,4.72 \%)$ and three milk samples $(3 / 40,7.50 \%)$ from buffaloes were positive for HEV RNA (Figure. 1). The positivity of HEV RNA in buffaloes in Guangxi Province was consistent with previous reports in other species of cattle: $3.23 \%(1 / 31)$ to $11.67 \%(7 / 60)$ in dairy cow in Xinjiang Province, Northwest China, in 2010 (Hu and $\mathrm{Ma}, 2010)$; 3.26\% (3/92) in yak in the Qinghai and Gansu provinces of Northwest China, in 2014 (Xu et al., 2014); and 3.00\% $(8 / 254)$ in yellow cattle in Shandong Province, Eastern China, in 2016 (Yan et al., 2016). However, the results were lower than $37.14 \%$ $(52 / 140)$ in Holstein cows in Dali, Yunnan Province, Southwest China, in 2016 (Huang et al., 2016), where mixed farming with swine, goat, and cattle is practiced.

We collected blood samples to investigate seroprevalence of HEV infection in buffaloes. To determine the anti-HEV antibodies in buffaloes, a double-antigen sandwich ELISA kit was used. Only one serum sample from buffaloes was positive for the anti-HEV IgM antibody (1/106, $0.94 \%$ ), and no sample was positive for the antiHEV IgG antibody. The seroprevalence of HEV in buffaloes was lower than that in cattle from the provinces of Guizhou $(4.00 \%, 1 / 25)$, Qinghai $(7.40 \%, 2 / 27)$ and Yunnan $(44.40 \%, 12 / 27)$ in 2010 (Geng et al., 2010) and in yellow cattle from the province of Shandong $(47.00 \%, 120 / 254)$ in 2016 (Yan et al., 2016). 


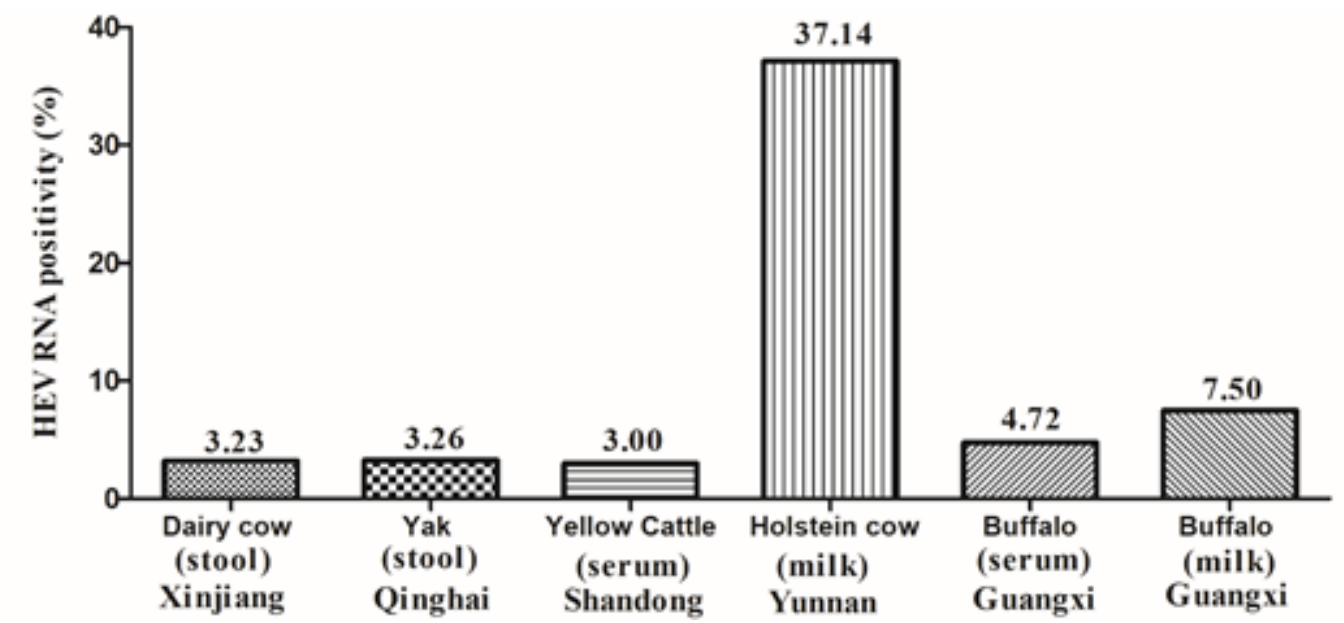

Figure 1. Positive rate of HEV RNA in cattle in China.

Phylogenetic analysis was performed based on HEV ORF2 (partial) sequences isolated from buffaloes (348 bp). All eight HEV strains isolated from buffaloes in Guangxi Province belong to genotype $4 \mathrm{HEV}$. These strains share $98.00 \%$ $100 \%$ similarity with each other. One of them was submitted to the GenBank database (KU974931). The homology analysis indicated that these buffalo HEV strains share 95.10\%-95.70\% homology (KF736234) to yak HEV isolated from the Qinghai and Gansu provinces of Northwest China (Xu et al., 2014); 98.30\%-100\% similarity (KU356187) to Holstein cow HEV isolated from Dali, Yunnan Province, Southwest China (Huang et al., 2016); and $84.50 \%-85.90 \%$ similarity (KU904280) to yellow cattle HEV isolated from Shandong, Eastern China (Figure. 2) (Yan et al., 2016).

\section{DISCUSSION}

HEV infection has been recognized as a zoonotic disease. A recent report has demonstrated that raw/undercooked milk from cows can lead to active HEV infection in non-human primates (Huang et al., 2016). Moreover, the consumption of camel meat and milk is associated with chronic HEV infection (Park et al., 2016). In the present study, a high prevalence of active HEV infection was found in the serum $(4.72 \%)$ and milk $(7.50 \%)$ of buffaloes in Guangxi Province, China. In this area, buffaloes are regarded as an important component of the agricultural economy. Buffalo milk is a new and popular dairy product in Southwest China. Milk is believed to be the best nutriment for people who are undernourished or pregnant. Thus, the consumption of raw/undercooked milk or beef from HEV-infected buffaloes is involved with a high risk of HEV infection from buffaloes to humans.

HEV can be zoonotically transmitted from many domestic animals, including deer, camels, swine, and cows (Choi et al., 2013; Huang et al., 2016; Lee et al., 2016; Miyashita et al., 2012), to humans or non-human primates. Active HEV infection has been found in cattle in many areas of China, such as dairy cow in Xinjiang Province, yak in the Qinghai and Gansu provinces, yellow cattle in Shandong Province, and Holstein cows in Yunnan Province (Hu and Ma, 2010; Huang et al., 2016; Xu et al., 2014; Yan et al., 2016). In the present study, a high prevalence of HEV infection was found in buffaloes of Guangxi Province, China. Although the seroprevalence of $\mathrm{HEV}$ infection in buffaloes is low, the positive rate of HEV RNA in buffaloes is comparable to that in yak, yellow cattle, or dairy cow.

HEV genotype 3 and $4 \mathrm{HEV}$ have become the predominant HEV genotypes in China (Shuai et al., 2017; Zhang et al., 2009). All eight HEV strains isolated from buffaloes in Guangxi Province belong to genotype $4 \mathrm{HEV}$. Homology analysis of HEV isolated from buffaloes showed a high similarity to HEV isolated from Holstein cow (Huang et al., 2016) and yak (Xu et al., 2014). In summary, buffaloes may be a new natural reservoir of HEV. Further research is needed to access the potential for zoonotic transmission from buffaloes to humans. 
Hepatitis $E$ virus...

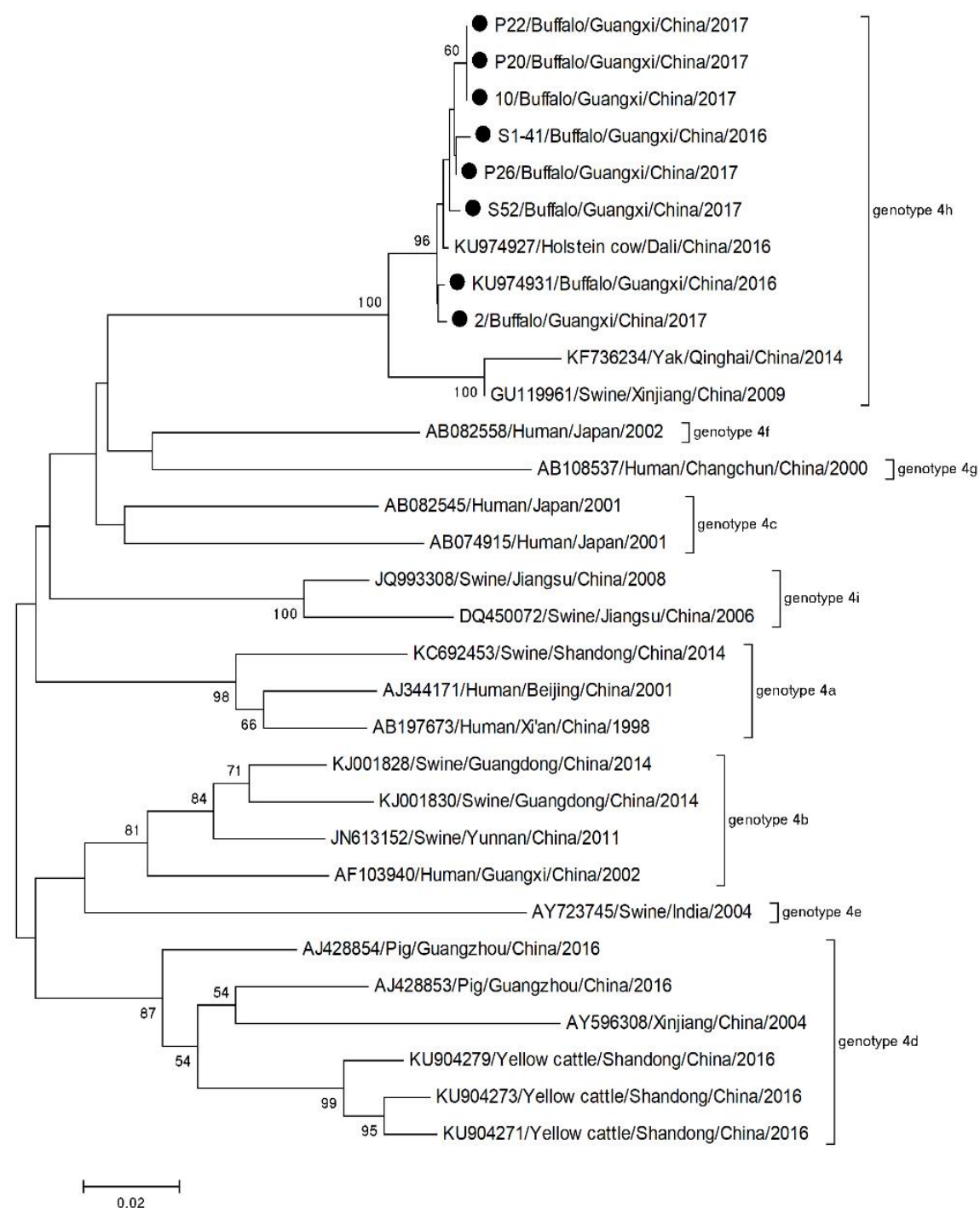

Figure 2. Phylogenetic tree based on the HEV ORF2 partial sequence (348bp) generated using the Neighbor-Joining method of the MEGA 5.1 program.

\section{ACKNOWLEDGEMENTS}

This study was supported by the National Natural Science Foundation of China (Grant number 81660338 and 81960370), Natural Science Foundation of Yunnan province (Grant number 2017FA036 and 2018FB132), Fundamental Research Funds for the Central Universities (Grant number 20162X310179-3) and PUMC Youth Fund (Grant number 3332019008 and 2017310038), and Training project of Kunming
University of Science and Technology (Grant number KKz3201660003).

\section{CONFLICT OF INTEREST}

The authors declare that they have no conflict of interest. All applicable international, national, and/or institutional guidelines for the care and use of animals were followed. 


\section{REFERENCES}

CHOI, J.Y.; LEE, J.M.; JO, Y.W. et al. Genotype-4 hepatitis $\mathrm{E}$ in a human after ingesting roe deer meat in South Korea. Clin. Mol. Hepatol., v.19, p.309-314, 2013.

COSSABOOM, C.M.; CORDOBA, L.; DRYMAN, B.A. et al. Hepatitis E virus in rabbits, Virginia, USA. Emerg. Infect. Dis., v.17, p.2047-2049, 2011.

GENG, Y.; WANG, C.; ZHAO, C. et al. Serological prevalence of hepatitis $\mathrm{E}$ virus in domestic animals and diversity of genotype 4 hepatitis $\mathrm{E}$ virus in China. Vector Borne Zoonotic Dis., v.10, p.765-770, 2010.

HOOFNAGLE, J.H.; NELSON, K.E.; PURCELL, R.H. Hepatitis E. N. Engl. J. Med., v.367, p.1237-1244, 2012.

HSIEH, S.Y.; MENG, X.J.; WU, Y.H. et al. Identity of a novel swine hepatitis $\mathrm{E}$ virus in Taiwan forming a monophyletic group with Taiwan isolates of human hepatitis E virus. J. Clin. Microbiol., v.37, p.3828-3834, 1999.

HU, G.D.; MA, X. [Detection and sequences analysis of bovine hepatitis $E$ virus RNA in Xinjiang Autonomous Region]. Chin. J. Virol., v.26, p.27-32, 2010 .

HUANG, F.; LI, Y.L.; YU, W.H. et al. Excretion of Infectious Hepatitis E Virus Into Milk in Cows Imposes High Risks of Zoonosis. Hepatology, v.64, p.350-359, 2016 .

HUANG, F.F.; HAQSHENAS, G.; GUENETTE, D.K. et al. Detection by reverse transcription-PCR and genetic characterization of field isolates of swine hepatitis E virus from pigs in different geographic regions of the United States. J. Clin. Microbiol., v.40, p.1326-1332, 2002.

LEE, G.H., TAN, B.H., TEO, E.C. et al. Chronic infection with camelid hepatitis $\mathrm{E}$ virus in a liver transplant recipient who regularly consumes camel meat and milk. Gastroenterology, v.150, p.355-357 e353, 2016

LI, X.; ZHAO, C.; HARRISON, T.J. et al. Investigation of hepatitis $\mathrm{E}$ virus infection in swine from Hunan province, China. J. Med. Virol., v.80, p.1391-1396, 2008 .

LONG, F.; YU, W.; YANG, C. et al. High prevalence of hepatitis E virus infection in goats. J. Med. Virol., v.89, p.1981-1987, 2017.

MIYASHITA, K.; KANG, J.H.; SAGA, A. et al. Three cases of acute or fulminant hepatitis $\mathrm{E}$ caused by ingestion of pork meat and entrails in Hokkaido, Japan: zoonotic food-borne transmission of hepatitis $\mathrm{E}$ virus and public health concerns. Hepatol. Res., v.42, p.870878, 2012.
NAVANEETHAN, U.; AL MOHAJER, M.; SHATA, M.T. Hepatitis E and pregnancy: understanding the pathogenesis. Liver. Int., v.28, p.1190-1199, 2008.

PARK, W.J.; PARK, B.J.; AHN, H.S. et al. Hepatitis E virus as an emerging zoonotic pathogen. J. Vet. Sci., v.17, p.1-11, 2016.

PURDY, M.A.; KHUDYAKOV Y.E. The molecular epidemiology of hepatitis E virus infection. Virus Res., v.161, p.31-39, 2011

REIN, D.B.; STEVENS, G.A.; THEAKER, J. et al. The global burden of hepatitis E virus genotypes 1 and 2 in 2005. Hepatology, v.55, p.988-997, 2012.

SHUAI,, J.B.; LI, L.H.; LI, A.Y. et al. Full genome analysis of swine genotype 3 hepatitis $\mathrm{E}$ virus isolated from eastern China. J. Zhejiang. Univ. Sci. B., v.18, p.549-554, 2017.

SMITH, D. B.; SIMMONDS, P.; JAMEEL, S. et al. Consensus proposals for classification of the family Hepeviridae. J. Gen. Virol., v.96, p.1191-1192, 2015.

SMITH, D.B.; SIMMONDS, P. JAMEEL, S. et al. Consensus proposals for classification of the family Hepeviridae. J. Gen. Virol., v.95, p.2223-2232, 2014.

TAKAHASHI, M.; NISHIZAWA, T.; SATO, H. et al. Analysis of the full-length genome of a hepatitis $E$ virus isolate obtained from a wild boar in Japan that is classifiable into a novel genotype. J. Gen. Virol., v.92, p.902-908, 2011.

TAM, A.W.; SMITH, M.M.; GUERRA, M.E. et al. Hepatitis E virus (HEV): molecular cloning and sequencing of the full-length viral genome. Virology, v.185, p.120-131, 1991

WOO, P.C.; LAU, S.K.; TENG, J.L. et al. New hepatitis E virus genotype in bactrian camels, Xinjiang, China, 2013. Emerg. Infect. Dis., v.22, p.2219-2221, 2016.

XU, F.; PAN, Y.Y.; BALOCH, A.R. et al. Hepatitis E virus genotype 4 in Yak, Northwestern China. Emerg. Infect. Dis., v.20, p.2182-2184, 2014.

YAN, B.; ZHANG, L.; GONG, L. et al. Hepatitis E virus in yellow cattle, Shandong, Eastern China. Emerg. Infect. Dis., v.22, p.2211-2212, 2016.

ZHANG, W.; YANG, S.X.; REN, L.P. et al. Hepatitis $E$ virus infection in Central China reveals no evidence of cross-species transmission between human and swine in this area. Plos. One., v.4, p.e8156, 2009. 